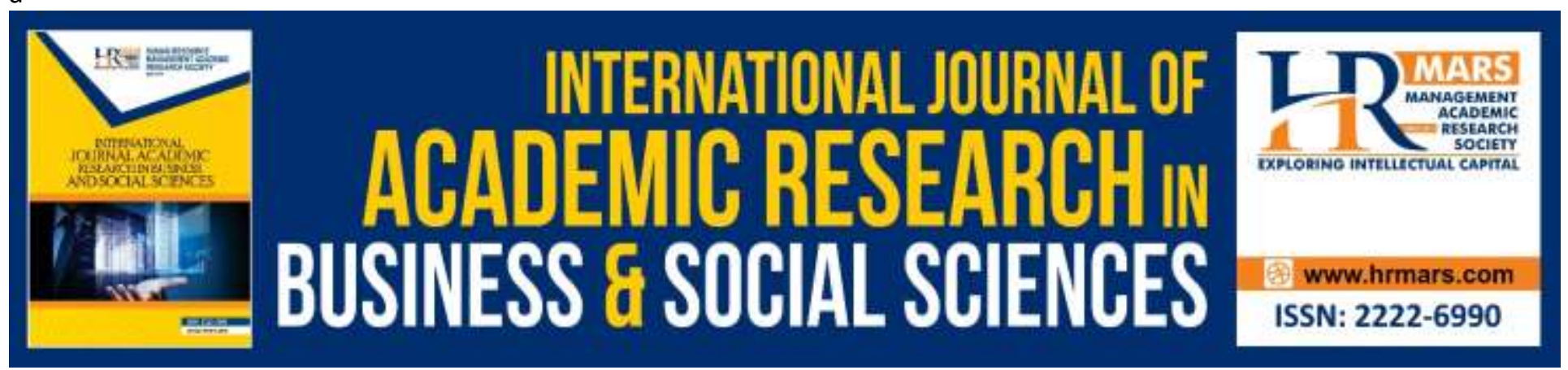

\title{
Impact of Trade Liberalization on Indonesian Export to South Korea, Japan, and China
}

Silva Nur Rizha Fajriyanti, Rossanto Dwi Handoyo, Abdul Rahim Ridzuan, Mohamad Idham Md Razak

To Link this Article: http://dx.doi.org/10.6007/IJARBSS/v10-i5/7247

DOI:10.6007/IJARBSS/v10-i5/7247

Received: 26 March 2020, Revised: 29 April 2020, Accepted: 13 May 2020

Published Online: 30 May 2020

In-Text Citation: (Fajriyanti et al., 2020)

To Cite this Article: Fajriyanti, S. N. R., Handoyo, R. D., Ridzuan, A. R., \& Razak, M. I. M. (2020). Impact of Trade Liberalization on Indonesian Export to South Korea, Japan, And China. International Journal of Academic Research in Business and Social Sciences, 10(5), 762-769.

\section{Copyright: (C) 2020 The Author(s)}

Published by Human Resource Management Academic Research Society (www.hrmars.com)

This article is published under the Creative Commons Attribution (CC BY 4.0) license. Anyone may reproduce, distribute, translate and create derivative works of this article (for both commercial and non-commercial purposes), subject to full attribution to the original publication and authors. The full terms of this license may be seen

at: http://creativecommons.org/licences/by/4.0/legalcode

Vol. 10, No. 5, 2020, Pg. 762 - 769

Full Terms \& Conditions of access and use can be found at http://hrmars.com/index.php/pages/detail/publication-ethics 


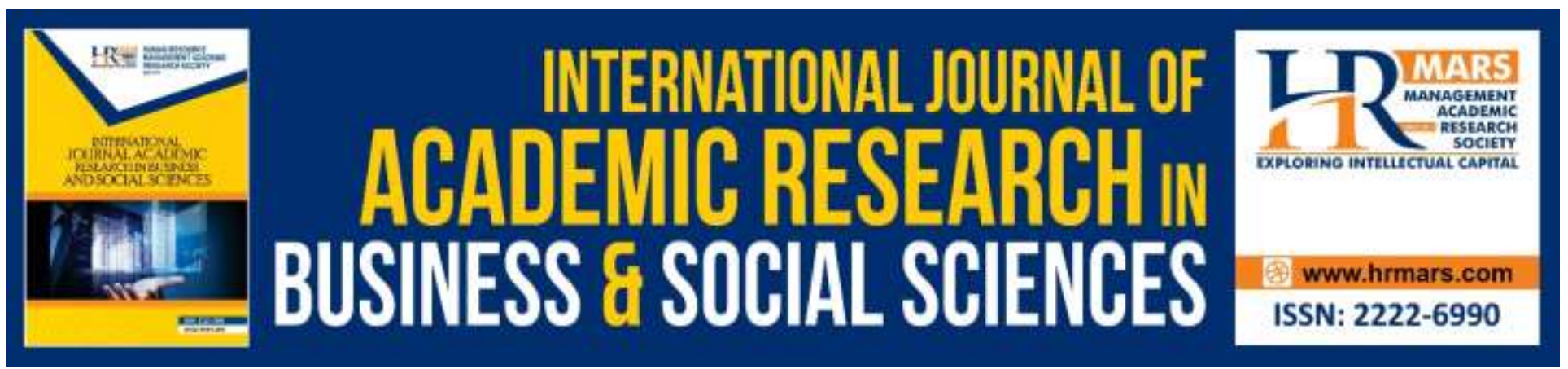

\title{
Impact of Trade Liberalization on Indonesian Export to South Korea, Japan, And China
}

\author{
Silva Nur Rizha Fajriyanti \\ Faculty of Economics and Business, Universitas Airlangga \\ Email: fajriyanti.silva27@gmail.com \\ Rossanto Dwi Handoyo \\ Faculty of Economics and Business, Universitas Airlangga, Indonesia \\ Email: Rossanto_dh@feb.unair. ac.id
}

\begin{abstract}
Abdul Rahim Ridzuan, Mohamad Idham Md Razak
Faculty of Business and Management, Universiti Teknologi MARA, Melaka Campus, Malaysia

Email:Rahim670@staf.uitm.edu.my, iedham@warga.uitm.edu.my
\end{abstract}

\begin{abstract}
One of the characteristics of an open economy is the contribution of international trade in the economy. Numerous trade agreements have been made to reduce international trade barriers. This study aims to determine the impact of trade liberalization on Indonesian exports to three major trading partners in East Asia, South Korea, Japan and China. The impact of liberalization on exports was examined using a gravity model and a panel with a period of 20 years. The independent variables used in this study are tariff, degree of openness, population, exchange rate, GDP, and distance. The results of this study indicate that trade liberalization, viewed from the tariff and degree of openness has a significant effect on exports. Other influencing variables are GDP, population, and exchange rate. The variable of distance does not affect Indonesian exports to the three trading partner countries.
\end{abstract}

Keywords: Export, Liberalization, Degree of Openness, Tariff, Gravity Model.

\section{Introduction}

Trade liberalization was signed as international agreements aim to reduce trade barriers, and this is also applied in Indonesia. The agreement causes the entry of imported goods to be easier and cheaper than before. If Indonesia does not make ample preparation, the local products cannot compete with foreign products. It is important to note that, over the past few years, Indonesia's exports have shown a downward trend since 2011. 
INTERNATIONAL JOURNAL OF ACADEMIC RESEARCH IN BUSINESS AND SOCIAL SCIENCES

Vol. 10, No. 5, May, 2020, E-ISSN: 2222-6990 @ 2020 HRMARS

Figure1.1. Export and Import of Indonesia during 2000-2015

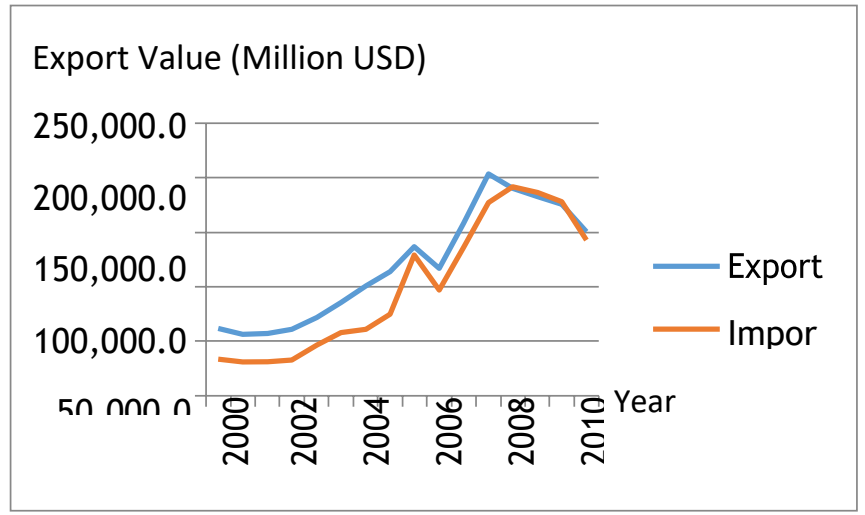

Source: Central Bureau of Statistics, 2017, processed data

This condition can be a problem if the import volume exceeds the export volume. The more imported goods enter a country, it can reduce the country's foreign exchange reserves when adequate exports are not met. In this condition, trade liberalization will cause a bad impact on the country's economy.

The difference between this study and previous studies is seen in terms of the focus of the discussion. This study focuses on the impact of trade liberalization, namely the reduction of tariffs on exports and the contribution of international trade to the GDP (degree of openness). The chosen trade partners are South Korea, Japan and China because these three countries are consistently ranked in the Top 10 of Indonesia's main export destination countries, and the three countries are situated in one region. The market share of Indonesia's exported goods to the three countries is quite large, at 27.5 percent. The amount exceeds the combined market share of Indonesian exports to Singapore, Malaysia, Thailand and the Philippines, which amounted to 20 percent.

The period chosen in this study was from 1996 to 2016 because the period marked the period before and after the implementation of the trade agreement to reduce tariffs. The year 1996 was chosen because, in 1996-1997, the import tariffs to China experienced a fairly high decline from $22.02 \%$ to $16.66 \%$. The purpose of this study is to analyze the impact of trade liberalization, especially seen from the reduction of tariffs and the ratio of degrees of openness, as well as the influence of other variables such as exchange rates, population, real GDP, and the distance between Indonesia and South Korea, Japan and China, on Indonesian exports.

\section{Literature Review}

\section{Absolute Advantage Theory}

Absolute advantage theory explains that between two countries with two products, specialization and trade will be advantageous if the state has a cost advantage (few employ labor) (Carbaugh, 2008: 29).

\section{Comparative Advantage Theory}

The theory of comparative advantage states that countries with less efficient production can still trade with specialization and export goods that are more efficiently produced (Carbaugh, 2008: 30). 
INTERNATIONAL JOURNAL OF ACADEMIC RESEARCH IN BUSINESS AND SOCIAL SCIENCES

Vol. 10, No. 5, May, 2020, E-ISSN: 2222-6990 @ 2020 HRMARS

\section{Heckscher-Ohlin Theory}

A country tends to export goods that are produced intensively and using abundant factors

(Krugman et al., 2012: 121). Trading is profitable because it allows a combination of two or more items.

\section{Gravity Model}

Based on Carbaugh (2008), the gravity model is a model that connects trade between two countries (exports and imports) according to the economic size and distance between the two countries.

\section{Technological Gap Theory}

Based on this theory, the role of technology as a technique, capital goods, and new consumer goods is to minimize production costs. Technology has a vital role in trade (Cotsomitis et al., 1991).

\section{Overlapping Demand Theory}

This theory states that the country produces goods to meet needs and export excess production. A country trades with a country with almost similar abundance (Bukhari et al., 2005).

\section{Tariff Policy}

Tariffs are taxes imposed on goods from other countries upon entering the territory of a country. Tariffs generally aim to eliminate imported goods to enable competition among domestic goods (Hovey and Rehmke, 2008: 68-69). Consumers tend to be at a disadvantaged position because they would be the ones who bear the tariff (high price). Exporters bear more burdens because products that are charged with tariffs will be sold at a higher price, and that can affect consumer demand (Ministry of Trade, without years).

\section{Research Method}

This study uses a quantitative approach to descriptive econometrics, which is a combination of mathematical analysis, statistics, and economic theory. This study used a regression method that uses a panel, which is a combination of time series and cross-section (Gujarati, 2012: 235). The panel data regression method includes more than one time period and more than one sample. Using panel data regression, the best models would be chosen between PLS (OLS Panel), REM (Random Effect Model), and FEM (Fixed Effect Model), and it would be based on the Breusch-Pagan Lagrange Multiplier test, Chow-test and Hausman test. The dependent variable $(Y)$ in this study is Indonesian exports to South Korea, Japan, and China. The independent variables (X) are the exchange rate (X1), partner GDP (X2), tariff (X3), degree of openness (X4), partner population (X5), and distance (X6).

\section{Results and Discussion Results}

PLS regression shows insignificant distance to exports with a probability of 0.520 and a significance level of $(\alpha)$ of ten percent. Other variables show significant results; namely, real GDP has a probability of 0,000 ; the population has a probability of 0.002 ; the degree of trade openness has a probability of 0,000 ; average tariff with a probability of 0.071 ; and the probability of a real exchange rate of 0,000 . Variables that have a positive effect on exports are real GDP, population, and degree of openness of trade with the values of the coefficients of $0.7725005 ; 0,4687215$; and 22,57949. Distance variables, average rates, and exchange rates have a negative effect on exports with successive 
INTERNATIONAL JOURNAL OF ACADEMIC RESEARCH IN BUSINESS AND SOCIAL SCIENCES Vol. 10, No. 5, May, 2020, E-ISSN: 2222-6990 @ 2020 HRMARS

coefficients - 0.9236354; -0,0097266; and -0.5707668., Based on Chow-test, FEM was chosen because the probability of $\mathrm{F}$ was noted at 0.0227 . The estimation continued with REM regression.

Table 1 REM Regression Results

\begin{tabular}{llll}
\hline Independent Variable & Coefficient & Error Standard & P-value \\
\hline Exchange Rate & $-0,5707668$ & 2,172169 & 0.000 \\
DP & 0,7725005 & 0.095063 & 0.000 \\
Tariff & $-0,0097266$ & 0,0052915 & 0.066 \\
Degree of Openness & 22,57949 & 2,172169 & 0.000 \\
Population & 0,4687215 & 0,1407457 & 0.001 \\
Distance & $-0,9236354$ & 1,424938 & 0.517 \\
\hline Number of Observation & 63 & & \\
R $^{2}$ & 0,9753 & & \\
Prob. Chi-square & 0,0000 & & \\
\hline
\end{tabular}

The degree of significance $(\alpha)$ used in REM is 10 percent. The result of REM regression is shown in table 1. Exchange rate variables are negatively related to exports and are significant. GDP is positively related to exports and is significant. Tariff variables are negatively related to exports and are significant. The variable degrees of openness are positively related to exports and are significant. Population variables are positively related to exports and are significant. Variable distance is negatively related to exports and not significant.

Based on the Hausman test, the probability of chi-square (Prob> Chi2) is greater than the significance level $(\alpha)$ of 10 percent. In this study, the Chi-square probability is 0.1766 . The best model that REM gets was R2 in REM shows a value of 0.9753 . The independent variables in the model can explain the dependent variable of 97.53 percent, and the rest is explained by other variables outside the model.

The t-statistical test shows the effect of independent variables on individual dependent variables. The results of the t-test in the REM model regression show that the real GDP of the partner has a probability of 0,000 . This value is smaller than the significance level $(\alpha)$ of 10 percent. Therefore, GDP has a significant effect on exports. Exchange rates have a probability of 0,000 . Therefore, the exchange rate has a significant effect on exports. The average import tariff has a probability of 0.066 . Therefore, tariffs have a significant effect on exports. Indonesia's degree of openness towards the three trading partners has a probability of 0,000 . Therefore, the degree of openness has a significant effect on exports. The partner country population has a probability of 0.001 . Therefore, the population has a significant effect on Indonesia's exports to these three countries. The distance between Indonesia and the three trading partner countries has a probability of 0.517 . The probability of distance is greater than the level of significance $(\alpha)$ of 10 percent. Therefore, distance does not significantly affect Indonesia's exports to all three countries. Test F Statistics shows the effect of all independent variables on the dependent variable based on the probability of chi-square (Prob>Chi2). 0,000 chi-square probability. Together, the independent variables of the model affect the dependent variable.

The estimation model is written as follows:

$$
\ln X_{i t}=1,946138-0,5707668 \operatorname{lnRERit}+0,7725005 \operatorname{lnGDPit}-0,0097266 \text { Trfit }+
$$


INTERNATIONAL JOURNAL OF ACADEMIC RESEARCH IN BUSINESS AND SOCIAL SCIENCES Vol. 10, No. 5, May, 2020, E-ISSN: 2222-6990 @ 2020 HRMARS

$$
\text { 22,57949 DOPit + 0,4687215 In Popit - 0,9236354 InDistit + عit......... }
$$

REM estimation shows that the exchange rate is negatively and significantly related to exports. One percent increase in the Indonesian currency exchange rate against the currencies of trading partner countries will reduce Indonesia's exports by 0.57 percent. GDP is positively and significantly related to exports. A one percent increase in trade partner GDP will increase Indonesia's exports by 0.77 percent. Tariffs are negatively and significantly related to exports. A one percent increase in tariffs will reduce Indonesia's exports by 0.01 percent. The degree of openness is positively and significantly related to exports. An increase of one percent degree of openness will increase Indonesia's exports by 22.58 percent. The population is positively and significantly related to exports. One percent increase in population will increase Indonesia's exports by 0.47 percent. The study found that distance is negatively and insignificantly related.

\section{Discussion}

Indonesia's main exports are South Korea, Japan and China, based on the SITC Revision 2. In terms of products, from the largest to smallest amount are ranked as fuel and lubricants, raw materials (not edible), factory production (metal and iron), plant oils and animals, as well as transportation and machinery equipment. This condition shows that Indonesia has advantages in these products.

The exchange rate in this study is the Rupiah exchange rate compared to the exchange rates of the three trading partner countries. The exchange rate is negatively and significantly related to Indonesia's exports to South Korea, Japan and China. When depreciation occurs, exports will decrease. Japan experienced a similar situation because of the large amount of fuel imports will defeat the positive impact of depreciation, due to the cost of importing fuel. (Junko and Kiotaka, 2015; Fang et al., 2005). The negative value of linkage is also caused by the intermediate-input of exported goods. This condition affects the competitiveness of the price of exported goods (Ahmed et al., 2015).

The study examines the real GDP of the three trading partner countries, namely South Korea, Japan and China. GDP is statistically positive and a significant impact on Indonesian exports. GDP shows the size of a country's economy. The greater the economy of a country, the greater the level of international trade (Krugman et al., 2012: 41). The high GDP of the export destination country shows the high demand or level of consumption in the country. A similar case is seen in Bangladesh. The increase in GDP encourages the consumption of imported goods in Bangladesh (Hoque and Yusop, 2010).

This paper studied the tariff variable in terms of the average tariff variable for imported goods in South Korea, Japan and China. This variable is statistically and negatively related to Indonesian exports. Tariff reduction decreases the exporter burden, and consumer demand is increased as the price of goods have become more affordable. Reducing import tariffs in the three main export destination countries of Indonesia can encourage exports (Narayana and Khorana, 2014; Dabaere and Mostashari, 2010).

The degree of openness has a positive and significant impact on Indonesian exports. An increasingly open economy is shown by the increasing contribution of international trade, both in exports and imports to GDP. Increasing the flow of international trade will benefit the countries that enter trade agreements. With an increase in Indonesia's degree of openness, exports are expected to increase due to reduced production or consumption distortions (Krugman et al., 2012: 250).

The population of the three trading partner countries shows significant and positive statistics on Indonesian exports. The population can be used as a reference for a country's market share (Khan and 
Kalirajan, 2011). Increasing the population in the three trading partner countries can help to increase Indonesia's exports. An increase in the population of export destination countries will allow exporters to sell more. (Yang and Martinez-Zarzoso, 2014).

Distance is one of the important variables in the gravity model. A country tends to trade with closer distanced countries (Salvatore, 2011: 9). Distance is used as an approach to look into transportation costs (Krugman et al., 2012: 351-352). The estimation of this study shows that the distances between Indonesia and South Korea, Japan and China are not significant to exports. Other factors such as communication costs, control management, infrastructure, modern transportation technology, need to be considered in estimating transportation costs (Clark, 2007; Milner et al., 1998, Kleinert and Spies, 2011). Trade barriers are the factors that were taken into account in trade costs. A country tends to choose trading partners that apply little trade barriers, compared to closer trading partners that imposed a high cost of trade barriers (Ghazalian, 2015).

\section{Conclusion}

Exchange rates have negatively affected exports. When depreciation occurs, Indonesia's exports to South Korea, Japan and China should increase. This reverse condition is caused by imported products are used as the raw materials for export products (the price of raw materials is expensive and affects the price of the final product). The real GDP of South Korea, Japan and China have a positive effect on Indonesia's exports. When the economies of these three countries are improving, the export opportunities in Indonesia can increase due to better purchasing power among these countries.

Import tariffs and the degree of openness of Indonesia to South Korea, Japan and China have a significant effect on Indonesia's exports. Tariff reduction is expected to increase Indonesia's exports, and population has a significant effect on Indonesia's exports to these three countries. The large size of the population indicates a large export market. Distance is not significant in terms of the approach to transportation costs. Aside from distance, other factors should be considered, such as infrastructure, technology, trade barriers, and demand.

\section{References}

Ahmed, S., Appendino, M., \& Michele, R. (2015). Depreciations without exports? Policy Research Working Paper World Bank.

Carbaugh, \& Robert, J. (2008). International Economics. Eleventh Edition. Mason: Thomson Higher Education.

Clark, D. P. (2007). Distance, production, and trade. The Journal of International Trade \& Economic Development, 16(3), 359-371.

Dabaere, P., \& Shalah, M. (2010). Do tariffs matter for the extensive margin of international trade? An empirical analysis. Journal of International Economics, 81,163-169.

Fang, W., YiHao, L., and Henry, T. (2005). Export promotion through exchange rate policy: Exchange rate depreciation or stabilization?. Department of Economics Working Paper Series.

Ghazalian, \& Pascal, L. (2015). On the magnitude of the geographic distance effect on primary agricultural and processed food trade. Agribusiness, 31(2), 148-170.

Gujarati, D. N., \& Dawn, C. P. (2012). Basic Econometrics. Second book. $5^{\text {th }}$ edition. New York: McGraw-Hill.

Hoque, M. M., \& Yusop, Z. (2010). Impacts of trade liberalisation on aggregate import in Bangladesh: An ARDL bounds test approach. Journal of Asian E, 21, 37-52. 
INTERNATIONAL JOURNAL OF ACADEMIC RESEARCH IN BUSINESS AND SOCIAL SCIENCES

Vol. 10, No. 5, May, 2020, E-ISSN: 2222-6990 ㄷ 2020 HRMARS

Hovey, C., \& Rehmke, G. (2008). The Complete Ideal's Guides: Global Economics. Jakarta: Prenada Media Group.

Junko, S., \& Kiyotaka, S. (2015). Abenomics, yen depreciation, trade deficit, and export competitiveness. RIETI Discussion Paper Series 15-E- 020.

Khan, U. I., \& Kalirajan, K. (2011). The impact of trade costs on exports: An empirical modeling. Economic Modelling, 28, 1341-1347.

Kleinert, J., \& Spies, J. (2011). Transport cost in international trade. IAW Discussion Papers 74.

Krugman, P. R., Obstfeld, M., \& Melitz, M. J. (2012). International economics theory and policy. Ninth Edition. Harlow: Pearson Education Limited.

MapCrow. (2017). Retrieved on Sept 24, 2017 from http://www..mapcrow.info

Milner, C., Morrissey, O., \& Rudaheranwa, N. (1998). Protection, trade policy and transport costs: Effective taxation of Ugandan exporters. Credit Discussion Paper 7.

Narayanan, G. B., \& Khorana, S. (2014). Tariff escalation, export shares and economy-Wide welfare: A computable general equilibrium approach. Economic Modelling, 41, 109-118.

Salvatore, D. (1996). International Economics, 5th edition. Vol 1. Jakarta: Penerbit Erlangga.

Salvatore, D. (2011). International Economics: Trade and Finance. Tenth Edition. Singapore: John Wiley \& Sons (Asia) Pte Ltd.

Salvatore, D. (2014). International Economics. $9^{\text {th }}$ edition. Book 1. Jakarta: Penerbit Salemba Empat.

Statistics Indonesia. (2017). Retrieved on Sept 24, 2017 from: https://bps.go.id

Xiang, H., Kuang, Y., \& Li, C. (2016). Impact of the China- Australia FTA on global coal production and trade. Journal of Policy Modelling, 29(1), 65-78.

World Bank. (2017). Retrieved on Sept 24, 2017 from https://data.worldbank.org

World Integrated Trade Solution. (2017). Retrieved on Sept 24, 2017 from http://wits.worldbank.org

World Trade Organization. (2017).Retrieved on Sept 24, 2017 from https://www.wto.org

Yang, S., \& Zarzoso, I. M. (2014). A panel data analysis of trade creation and trade diversion effect: The case of ASEAN-China free trade srea. China Economic Review, 29, 138-151. 